\title{
Shrouded Histories: Outlaw and Lawmaker, Republican Politics and Women's Interests
}

\section{Kay Ferres}

IN this essay I want to discuss some problems of recovering the public career and political interests of the expatriate colonial writer, Rosa Campbell Praed. The paper will focus on Outlaw and Lawmaker (1893), which Robert Dixon has assigned to the 'colonial adventure' genre. But unlike the aristocratic 'Em' Waveryng in the novel, Rosa Praed did not write about picturesque colonials for exclusively British readers. Her work also circulated and publicised political ideas among her Australian readers. To me, the most striking thing about this text is its concern with the Irish question and the marriage question, both vigorously debated in the late 1880s in Britain, the United States and Australia. I would therefore argue that to read Outlaw and Lawmaker only in terms of the romance genre is to limit unnecessarily our understanding of the institutional locations from which Praed intervenes in public debate. In the discussion that follows, Outlaw and Lawmaker is recontextualised as an intervention in these two debates, particularly republicanism and the Irish question. Praed speaks from a range of different positions within these debates, and thus underlines the inherent difficulty of characterising women's interests.

Discussion of women's participation in public life has been constrained as much as it has been enabled by the too neatly conceptualised equation of gender with the separation of public and private spheres. In fact, as the example of Rosa Praed demonstrates, 'home' was a heterogeneous collection of experiences of expatriation, of colonial origin and political engagement, negotiated through her public life and literary career. In 1886, Rosa and her husband Campbell Praed Sailed to the United States on an extended tour. Despite a carefully maintained show of independence, it is clear that their fellow voyager, Justin McCarthy, had encouraged them to undertake the visit. He was a member of the Irish Parliamentary Party, a journalist, and Praed's literary collaborator. In the elections that had returned the Tories and ended hopes for Gladstone's Home Rule Bill, McCarthy had lost his seat by a narrow and disputed margin. In these circumstances, he was dispatched to New York, Providence, Boston and Chicago to reassure supporters, to explain the party's strategy to reverse its fortunes, and to raise funds. The Praeds' itinerary intersected with McCarthy's.

McCarthy's mission was not an easy one. Gladstone's Home Rule Bill provided for an Irish national parliament, but reserved powers over foreign affairs and the army for the imperial parliament, where the Irish would not be represented. Introducing the Bill in 1886, Gladstone had declared that it would '[knit] together, by bonds firmer and higher in their character than those which heretofore we have mainly used, the hearts and affections of this people and the noble fabric of the British Empire' (Kee 515). Many among Gladstone's own party were unpersuaded by this compromise, which failed to recognise the Irish claim to be a nation. And it did not sit well with the more radical Irish immigrants who greeted McCarthy - it would be difficult to convince them to continue to support ParnelPs party. Nevertheless, McCarthy was entertained lavishly, and received no more warmly than in Boston, where his reputation as a 'literary man' was as significant as his political standing. In Boston Rosa, too, was welcomed by the Fenian John Boyle O'Reilly, who in 1866 had been transported to Australia for crimes against the Crown. O'Reilly escaped in 1869 and made his way to America. A memorial in Boston commemorates this 'most influential Boston Irishman of the nineteenth century'.

Outlaw and Lawmaker had its beginnings in this tour, and Praed explicitly associates its hero, Morres Blake, with Boyle O'Reilly. Blake tells Elsie Valliant about his family connections:

The Blakes of Coola are a wild set, Catholics, and ... ardent Nationalists, the very stuff of which a Fenian is made. You may have heard too, of Boyle O'Reilly, who was tried and sentenced for inciting his regiment to revolt, and finally sent to Western Australia, from which he got away to America. My offence was the same.(277)

But Praed has not simply transported the story of a colourful adventurer to colonial Queensland: she is using the figure 
of Blake to invoke or incite debate in Australia about republican nationalist aspirations and Empire. Republican ideas informed popular debates about the nation's future in the late nineteenth century, but the traces of that argument all but disappeared, after federation saw the triumph of empire nationalism. Praed's novel allows us to trace that argument, and to make some conjectures about the reasons for its disappearance.

Outlaw and Lawmaker certainly is a colonial romance: but it is the story of a bushranger who is also an elected Member of Parliament, an Irish nationalist whose opportunity to resolve 'Irish wrongs' presents itself in a colonial parliament in Leichhardt's Town, not on College Green. Morres Blake takes office as Colonial Secretary, but has little patience with parliamentary solutions to political oppression. As Captain Moonlight, he robs the ruling classes to raise funds for the Irish cause. The novel is also an anti-romance, to the extent that its heroine, Elsie Valliant, rejects conventional understandings of marriage in favour of an idea of a properly contractual relationship. The narrative of Elsie and Blake's attraction, and of Blake's unmasking as Captain Moonlight, is embedded in a picturesque staging of the bush as a site of 'primeval' culture and of the uneven advance of 'civilisation'. The tale is offered to the reader as an interruption of the official histories of British colonialism in 'Leichhardt's Land' and of the emergent Australian nation. When Elsie Valliant tells Frank Hallett about Moonlight's holdup and his cool daring in its aftermath, two desires are at work in the structuring of the tale: Elsie's fascination with the outlaw as hero, and Hallett's need for confirmation of his own political aspirations. ${ }_{-}^{1}$ As it turns out, it is Hallett's desire which Praed's 'shrouded history' realises: its recovery of the 'strange tragic episode' of Blake's career can only contest the terms of its forgetting, and momentarily interrupt a colonial history propelled by a notion of national character embodied in the stalwart figure of the bushman.

Exposure is not the point of Blake's history: there is little mystery about Captain Moonlight's 'true' identity. The mystery pertains to his powerful presence, the passion that subtends his cold resoluteness, the magnetism which draws followers to his cause. Although John Boyle O'Reilly was a model for the character of Captain Moonlight, the correspondences with Parnell are inescapable: Blake's bearing is 'kingly', his speeches passionate and compelling, his parliamentary performance marked by a refusal to be bound by protocol. Blake's Fenian affiliation is the element of his history which resists textualisation, both for Praed in the context of the Home Rule debates and the parliamentary party's struggles for ascendancy in Ireland and in the House of Commons, and for Australian readers in the twenty-first century for whom nineteenth-century arguments for an Australian republic are relatively unknown. In such circumstances, the more predictable reading is that Blake is a mere adventurer (as Isaac Butt proclaimed Parnell to be [McCarthy, Ireland's Cause 63]), a view that the narrative works hard to counter. Elsie's attraction to him is charted from magnetic attraction to deep affinity; his feelings for her from reckless flirtation to selfless devotion. Praed's interest in theosophy and psychic research shows itself here: as well as Blake's and Elsie's personal history, national history is played out between the 'two eternities of race and soul'.2.

Blake's character expresses Irishness in its mythic and political dimensions. Irishness is signified as both race and culture. His name is 'about as old a name as there is in Ireland', he is given to dreaminess as much as to wild excitement, he speaks of a 'taint' in his blood that gives rise to passion and morbidity and accounts for his radicalism:

There are times when a mad thirst for excitement seizes me, works me to a frenzy. At these times I am mad. It's a taint in the Blake blood. I must have an outlet, or I should be in a lunatic asylum. You may take that as one excuse for me. The other is that I am a patriot to the depth of my heart, and I am sworn to work for my country's freedom. (278)

Blake's partner, Trant, presents a rougher face of Fenianism. He more closely resembles popular caricatures of Irish radicals; in him, Blake's aristocratic madness edges into fanaticism and unprincipled criminality. Trant recruits 'halfcastes' to the bushranging gang, using his uncanny, hypnotic powers to secure their loyalty. 3 But he too displays a Celtic charm, expressed through his singing of haunting love songs and 'The Wearing of the Green'. Trant and Blake share a history of exile in France, North Africa and America, but where Blake is at least partly disposed to parliamentary solutions to political differences, Trant is a revolutionary.

Though Blake sees his election victory as portending the redress of Irish wrongs, the regeneration of Ireland and the magnificent destiny of Australia, the novel does not articulate his nationalist political programs. Irish and Australian destinies do not converge, and Blake's radical, republican enterprise makes way for Hallett's liberalism. Blake himself disappears, just as late nineteenth-century republican narratives have all but disappeared in the official civic histories of the achievement of federation. Thus Blake's constituency, the radical miners of Goondi, and their interests recede as 
the narrative shifts to the 'picturesque' bush. If the inclusion of Blake's anti-colonialist radicalism disturbs an account of the emergence of a nationalist character and history embodied in the bushman, the inclusion of Elsie raises questions about the imbrication of gender and sexuality in both colonial and nationalist histories, for Elsie does not represent the kind of domestic femininity at once excluded and contained by imperialist and nationalist ideologies. She is neither the mother of the race, nor the moralist. Crucially, Elsie's sexuality marks her not as indifferently unconventional, but as actively contesting the terms of femininity's construction. The contrast of the two narratives highlights the extent to which each character's radicalism is recognisable, and able to be written.

Visiting aristocracy, in particular Lady 'Em' Waveryng, are treated to the spectacle of the corroboree and the 'native' parliament, but the contrast Praed most consistently strikes is between the English aristocracy, and the new strain of colonial whiteness:

This little group of nineteenth-century people, all young - almost all handsome, the outside band of stockmen and the two half-castes, and this inner circle - the men in their bushman's dress. Frank Hallett and Trant, stalwart and splendid with animal health and vigour; Lord Horace, with his Apollo face and that nameless stamp of old world aristocracy; Lady Waveryng with the same stamp - high-bred and yet simple, the natural product of centuries of civilisation; Mrs Allanby - a perfumed exotic, not altogether wholesome; Elsie - wild, tropical flower; and Minnie Pride -typically Australian, reminding one with a tendency for floral simile of a sprig of her own fresh native wattle. (251)

This strand of the narrative turns on romance and sexuality. Here the concern is with making appropriate matches, and not so incidentally, good breeding. Blake, with his tainted blood, and Elsie, a wild flower, are well matched, but not destined to reproduce. Frank Hallett is inevitably rejected by Elsie, but finds happiness with her sister, Ina. It is this more temperate couple who will produce good stock.

Elsie and Blake provide the romance plot: Elsie an antipodean Jane Eyre, who meets her hero at the creek crossing where Blake is unseated from his horse. But Elsie does not share Jane Eyre's virtue, and has none of her Evangelical zeal or moralism. Like Jane, Elsie does not see marriage as an end in itself, nor as a 'trade', but in colonial Leichhardt's Town her options present themselves differently:

I think it's a pity we weren't taught to earn our own living. I think it's a pity in a kind of a way that we are pretty. If we had been ugly there wouldn't have been so much bother about this marrying business. As it is there's nothing else for us to do ... Now if we had been governesses, or even plain needlewomen, there would never have been any necessity for falling in love. (42-43)

As it is, Elsie is rather more than a plain needlewoman, but in the colonial context of high masculinity ratios and anxiety about interracial marriage, she does not have the option of a profession open to the 'surplus' women in England (see Vicinus). In local society, she is an unattached woman, a problem compounded by her beauty and her very evident sexuality. Elsie's flirtatiousness calls into question the dichotomy of the pure and fallen woman which respectable colonial and bourgeois society works so hard to maintain:

The sense of conquest was intoxicating. All the men present whom she considered worth captivating she had reduced to abject subjection ... Perhaps the enjoyment was all the more intense because there mingled a strange sense of dread, a certain vague pain and expectancy which gave a keener edge to life, and might have been the thrill of a new sense. (97)

Elsie's sensuousness is dangerous, and her brush with danger comes in the person of the cosmopolitan Lord Astar, whose unscrupulous vanity is not apparent to her colonial innocence. Her repudiation of Astar is belated, but consistent with her principles of individual sovereignty. Frank Hallett's gallantry is also an expression of this view of marriage: that it is properly contractual, involving equal partners, and able to be revoked. If Elsie is valiant it is in her determination to discover her destiny and to live it, and not to use marriage as a means of subsistence. This point is underlined when she is abducted. Trant overpowers her with chloroform, a tactic that recalls the white slavery scandals contrived by W.T. Stead's Pall Mall Gazette. Trant's threat fails, but the naturalisation of abduction and seduction in romance narrative is the object of Praed's melodrama.

Outlaw and Lawmaker ends with a reflection on the events it has staged, and on writing national histories. Drawing 
attention to its restoration of the 'strange, tragic episode' of the Colonial Secretary, Morres Blake's, secret lives as a bushranger and as a Fenian rebel, it notes the erasures and mystifications that sustain dominant narratives. But it enacts an erasure of its own in the drama of Blake's death and in consigning its heroine, Elsie Valliant, to the borderlands of hysteria and notoriety: a suitably melodramatic, nineteenth-century feminine ending. Elsie complains to Blake that she has 'no outlet'. The narrative offers no redirection of her energies in 'woman's mission', no future as a wife, or a teacher, or a missionary. Elsie's end is hysterical illness and a bohemian existence in Rome. Robert Dixon connects Lady Waveryng's suppression of Moonlight's identity, and Praed's excision of Blake's history, on the basis that 'the material would compromise respectable life' (Dixon 44). This argument assumes a notion of home as the site of middle-class feminine domestic authority which has a 'sealed in consistency', to recall Deleuze and Guattari. It seals off the private world of romance and sexuality, occupied by women, from the public realm of politics, occupied by men. Elsie experiences colonial life in just this way, but Praed's autobiographical writing and her collaborations with Justin McCarthy demonstrate that she herself did not. In any case, analysis of the heroine's, and the text's, resistances and appropriations still leaves us with a question: how can the recovery of women's private lives provide a basis for a revaluation of their status as subjects in history, as female citizens? For while the narrative restores Blake's 'shrouded history' by linking two colonial histories, through his political enterprise to promote 'the regeneration of Ireland and the magnificent destiny of Australia', it is the case that, however unconventional a heroine she is, Elsie's life cannot be made to signify anything outside itself.

Contemporary feminist scholarship has seen a revision of the boundaries of gender and genre, and a restoration of feminine narratives which allow new readings of Elsie's excessive desires. ${ }_{-}^{4}$ Nineteenth-century definitions of gender as sexual difference constituted the feminine as that which is outside the ethical, civil domain, and within the 'natural' realm of home and family. One of the perils of reconstituting the female subject is linked to this representation of femininity, institutionalised by nineteenth-century disciplines - medicine, science, law - and organised through the separation of public and private spheres. However much we critique this notion of gender, we are always in danger of reproducing it, of confirming the littleness of women's lives. The project of recovery is dogged, not only by the lack of sources or evidence, but also by the lack of a larger social and political paradigm to lend significance to women's lives. 'Loss and absence', as Carolyn Steedman laments, remain 'loss and absence' (248-49). In the case of Elsie Valliant, and of Rosa Praed, those untextualisable properties relate to the range and diversity of women's political commitments. Patricia Clarke's recently published biography Rosa! Rosa! illustrates this point. Clarke's narrative represents Praed's life as a spiritual quest which leads her away from Australia and from the conventions of heterosexual marriage to her 'twin soul' Nancy Harward. This narrative is underwritten by the feminist recovery of nineteenth-century 'women's friendships', notably the work of Lilian Faderman. That history reinterprets the 'silences' of private life and domestic relationships, but also performs its own effacements: in Clarke's account of Praed's life, very little is made of her political interests apart from sexual politics, or of the way theosophy operated as a public political discourse.

Moira Gatens offers an account of gender that refuses the dualistic articulation of sexual difference. She situates the body historically in terms of investments in desires, capacities and material forms, and proposes that gender be understood 'not as the effect of ideology or cultural values but as the way power takes hold of and constructs bodies' (Gatens 132). This redefinition enables more particular things to be said about gender than that it is 'culturally constructed', or that properties and attributes associated with masculinity and femininity are arbitrarily and unevenly distributed across, and enacted through, sexed bodies. It provides an account of 'subjects conceived as multiply constructed [and] capable of a range of commitments' (Lowe 197). Thus, it allows women's interests in politics in the 1880s to be understood not as being confined to suffrage, nor contained by 'separate spheres' rhetoric. It allows an analysis of negotiations of gender within the discourses of nationalism, colonialism and sexuality to displace the homogenisation of the history of colonialism.

Rosa Praed's position as an expatriated white colonial woman gave her a different take on the notions of 'home' and on 'race'. While she does not completely unravel evolutionist and imperialist ideas of racial superiority, she does understand race as a category that encompasses whiteness, rather than treating whiteness as an undifferentiated norm against which 'race' signifies deviation. She takes up nineteenth-century anthropological discourse of the 'types' of 'man' to differentiate Englishness from Irishness, and to specify the uneven development of variant 'species'. This use of anthropology promotes a limited anti-colonialism by targeting the degeneracy of certain aristocratic strains of Englishness, and engaging with a nationalist discourse about race. Her interventions in the marriage debates of the 1880s and 1890s are not underwritten by the Evangelicist moral authority that characterises so much nineteenth- 
century British feminism: she does not appeal to home as the protected, bounded space the safety of which is predicated on the exclusion or repression of difference. Instead, her colonial awareness of 'not being home' constitutes a position from which she can observe the operations of imperial and masculine power (Martin and Mohanty 196).

In the period of her collaboration with Justin McCarthy, Rosa Praed was a frequent visitor to the House of Commons. The Irish question dominated parliamentary politics, and Rosa Praed's own account of her interests reflects that: in 1912, after Justin McCarthy's death, she published his letters to her as Our Book of Memories, a voluminous correspondence. Though she is circumspect about her own part in that correspondence, Praed does declare that her own passionate support for the nationalist cause diminished after McCarthy took over as leader of the parliamentary party, and she witnessed the rapid decline in his health. Praed saw the action at the House of Commons from multiple sites: she met McCarthy on the Terrace, a 'brilliant social institution' (McCarthy, Story of an Irishman 91), and in the small Members' Dining Room, where she often sat alone with a book if the division bells had recalled him to the chamber. She observed the debate from the two vantage points offered to women: the cage of the Ladies Gallery, and the peephole in the brass door of the chamber. The peephole afforded a 'natural pictorial point of view' (McCarthy and Praed 10) to ladies standing on a leather chair in a niche provided for their exclusive use. While not wanting to pass too quickly over this vision of female voyeurism, I want to emphasise active spectatorship. Whether from behind the grille of the gallery, or awkwardly perched on the chair, women could gaze at will on the action in the House.

As Rosa Praed was taking in both the distanced and ground level view of an exclusively masculine political terrain, the impressionists Berthe Morisot and Mary Cassatt were painting women in public and social spaces - at the opera, in parks, and on balconies overlooking the streets. In these paintings, the space women occupy is strongly demarcated, sometimes by physical features such as banisters, balustrades and walls, at others by the picture planes and compositional arrangement. Morisot and Cassatt represent women in command of the physical and psychological spaces they occupy: these women presume to look at, and engage with, the world around them. If alone, they are not caught in narcissistic self-absorption, but engrossed in work or lost in thought. As Griselda Pollock has argued, 'The features in the paintings ... of proximity, intimacy and divided spaces posit a different kind of viewing relation at the point of both production and consumption' (84-85). I want to argue that the Ladies' Gallery was a site that similarly reorganised viewing and social relations; interpreting it this way disrupts the construction of gender as active masculinity and passive femininity, and spatial relations which define marginality as always subordinated to the centre. Instead, the margin can be thought of as 'a critical moment, rather than a de-centred moment ... an accomplice of the centre' (Spivak281).

The domain of women's political interests extended beyond the floor of the Parliament and party political meetings to private associations, the press, the theatre and to fiction. The marriage question, so crucial to Praed's fiction, was debated in all these locations. Mona Caird, whom Praed occasionally encountered in the parliamentary precinct, posed the question 'Is marriage a failure?' in the Westminster Review in August 1888. Caird's essay elicited an overwhelming response in the pages of the Daily Telegraph, which received some 27,000 letters on the subject (Bland 146). Caird's own view was uncompromising: marriage, given the circumstances of coverture, expressed the same idea -purchase of the woman's body - as prostitution. In its place, she advocated a private, free contract based on comradeship and equality, and on 'a full understanding of the obvious right of the woman to possess herself body or soul, to give or withhold herself ... exactly as she will' (Bland 148). The two dimensions of this argument were important to feminist campaigns of the period: advocacy of free unions went hand in hand with a concern about voluntary motherhood. So it is that the characters in Outlaw and Lawmaker endorse the idea of marriage as a contractual and a reciprocal arrangement.

Praed had taken up the issue of divorce law reform in The Bond of Wedlock, published in 1887, the year prior to the publication of Caird's 'Is Marriage a Failure?' This novel, like Outlaw and Lawmaker, demonstrates that Praed considered marriage a crucial issue in her colonial narratives, a problem not simply of convention and individual choice, but a question bound up with a national ethos. The book was subsequently staged by the actress-manager Mrs Bernard Beere in 1888 as Ariane. The notoriety the play attracted probably derived as much from the flurry caused by Mona Caird as from its disturbingly 'French' tendencies (see Ferres), In her letters to Rosa, Nora Murray-Prior broaches contemporary debates about divorce, the medical management of childbirth, and contraception, in her commentary on her own experience of colonial life: 'the bearing of children and the making of jams'. Nora reports Queensland readers' alarm that Rosa was 'growing extremely French in your ways'. 5 As their correspondence 
continues, Nora is increasingly attracted to 'free thinking' on the subject of marriage, and repudiates the imperialist appeal to women as mothers of the race. Polygamy, she ventures, would be preferable to incessant childbearing in hot climates, and her mention of incompetent obstetricians, neonatal deaths and maternal morbidity speak directly to the politicisation of these issues. While eugenicist discourse about racial purity underwrote pronatalist programs, feminist interests drew on the same discourse to promote the limitation of childbirth and protection of women's health. But as Lucy Bland observes, any feminist 'edge' to such discourse has long disappeared from view (157).

Restoring that edge to discussion of women's participation in public life requires attention to the variety of institutional locations in which they found themselves, and to the variety of forms in which political thought was articulated and ideas were circulated and contested. In Outlaw and Lawmaker, Frank Hallett and Ina are the bearers of the new nation's destiny. Their ascendancy overshadows the forgotten traditions that sustained Blake's republican sentiment, and Elsie's yearning for the possibilities realised by the 'New Woman' in metropolitan public spaces, which have been passed over by later critics. Reassessing Rosa Praed's career and her representation of women's interests requires an understanding of her location as an expatriate colonial writer, for if we take for granted the dichotomising of public and private along gendered lines that novels such as Outlaw and Lawmaker and The Bond of Wedlock contest, then, as Steed-man claims, the littleness of women's lives is merely reinforced.

\section{Notes}

1. Robert Dixon's discussion of the workings of Elsie's desire in this narrative is not one I'd disagree with, but he dispenses too quickly with Hallett.

2. Cf W.B. Yeats' 'Under Ben Bulben,' in W.B. Yeats: Selected Poetry, 206.

3. The Daily News 1 April 1887 carried a report on Charcot's experiments with hypnotism at the Salpetriere, noting that hysterically disposed persons could be induced to crime and unquestioning obedience when hypnotised, and that even blameless persons would maintain a secrecy that would defy ordinary means of detection. A clipping of this report is in Rosa Praed's papers in the Oxdey Library.

4. Robert Dixon offers an insightful reading along these lines, 38-44.

5. Nora Murray Prior to Rosa Campbell Praed, 29 October 1881, Oxley Ms OM 81-71, Fiche 3.

\section{Works Cited}

Bland, Lucy. 'The Married Woman, the "New Woman" and the Feminist: Sexual Politics of the 1890s.' Equal or Different: Women's Politics 1800-1914. Ed Jane Rendall. Oxford: Biackwell, 1987. 141-64.

Burton, Antoinette M. The White Woman's Burden: British Feminists and "The Indian Woman", 1865-1915'. Western Women and Imperialism: Complicity and Resistance. Ed Nurpur Chaudhuri and Margaret Strobel. Bloomington: Indiana UP, 1992. 137-57.

Caine, Barbara. Victorian Feminists. Oxford: Oxford UP, 1992.

Caird, Mona. 'Marriage.' Westminster Review 130 (August 1888): 186-201.

Chakrabarty, Dipesh. Provincialising Europe: Historical Difference and Postcolonial Thought. Princeton: Princeton UP, 2000.

Clarke, Patricia. Rosa! Rosa! A Life of Rosa Praed, Novelist and Spiritualist. Melbourne: Melbourne UP, 1999.

Davies, Robertson. The Mirror of Nature: The Alexander Lectures. Toronto: U of Toronto P, 1983. 
Dixon, Robert. Writing the Colonial Adventure: Race, Gender and Nation in Anglo-Australian Popular Fiction, 18751914. Melbourne: Cambridge UP, 1995.

Ferres, Kay. 'Women Making a Spectacle of Themselves: Rosa Praed, Melodrama and Marriage Reform. 'Australasian Drama Studies 23 (1993): 56-64. Gatens, Moira. 'Power, Bodies, and Difference'. Destabilizing Theory: Contemporary Feminist Debates. Ed. Michele Barrett and Anne Phillips. Cambridge: Polity, 1992. 120-37.

Hirst, John. The Sentimental Nation: The Making of the Australian Commonwealth. Melbourne: Oxford UP, 2001.

Irving, Helen. 'Who Were the Republicans?' Crown or Country? The Traditions of Australian Republicanism. Ed. David Headon, James Warden and Bill Gammage. Sydney: Alien \& Unwin, 1994.

Jalland, Pat. Women, Marriage and Politics 1860-1914. Oxford: Oxford UP, 1988.

Kee, Robert. The Laurel and the Ivy: The Story of Charles Stewart Parnell and Irish Nationalism. Hannondsworth: Penguin, 1993.

Lowe, Lisa. Critical Terrains: French and British Orientalisms. Ithaca: Cornell UP, 1991.

McCarthy, Justin. Ireland's Cause in England's Parliament. Preface by John Boyle O'Reilly. Boston: Triknor, 1888.

—. The Story of an Irishman. London: Chatto \& Windus, 1904.

—

Martin, Biddy, and Chandra Talpade Mohanty. 'Feminist Politics: What's Home Got to Do with It?' Feminist Studies/Critical Studies. Ed. Teresa de Lauretis. London: Macmillan, 1988. 191-212.

Melleuish, Gregory, and Geoff Stokes. 'Australian Political Thought.' Creating Australia: Changing Australian History. Ed. Wayne Hudson and Geoffrey Bolton. Sydney: Allen \& Unwin, 1997. 111-21.

Morris, Meaghan. Ecstasy and Economics: American Essays for John Forbes. Sydney: EmPress, 1992.

Murray-Prior Papers, Oxley Memorial Library, State Library of Queensland, OM81-71. Murray-Prior Papers, National Library of Australia.

O'Donnell, F.H. A History of the Irish Parliamentary Party, Vol 11. 1910. New York: Kennikat, 1970.

Pollock, Griselda. 'Modernity and the Spaces of Femininity,' Vision and Difference: Femininity, Feminism and the Histories of Art. London: Routledge, 1988. 50-90.

Praed Papers, Oxley Memorial Library, State Library of Queensland, OM64-1. Praed, Rosa. Ariane, or the Bond of Wedlock. London: Routledge, 1888.

—. Outlaw and Lawmaker. 1893. London: Pandora, 1988.

- The Bond of Wedlock: A Tale of London Life. 1887. London: Pandora, 1987. Praed, Rosa Mackworth. Our Book of Memories: Letters of Justin McCarthy to Mrs. Campbell Praed. London: Chatto \& Windus, 1912.

Spivak, Gayatri Chakravorty. 'The New Historicism: Political Commitment and the Postmodern Critic.' The New Historicism. Ed. H. Aram Veeser. London: Routledge, 1989. 277-92.

Steedman, Carolyn. Childhood, Culture and Class in Britain: Margaret McMillan 1860- 1931. London: Virago, 1990.

Vicinus, Martha. Independent Women: Work and Community for Single Women 1850- 1920. London: Virago, 1985. 
Walker, Linda. 'Party Political Women: A Comparative Study of Liberal Women and the Primrose League, 18901914.' Equal or Different: Women's Politics 1800-1914. Ed. Jane Rendall. Oxford: Blackwell, 1987. $165-91$.

Yeats, William Butler. Selected Poetry. Ed. Norman A. Jeffares. London: Macmillan, 1962. 